\title{
Air Turbines for Wave Energy Conversion
}

\author{
Manabu Takao ${ }^{1}$ and Toshiaki Setoguchi ${ }^{2}$ \\ ${ }^{1}$ Department of Mechanical Engineering, Matsue College of Technology, 14-4, Nishiikuma-cho, Matsue-shi, Shimane 690-8518, Japan \\ ${ }^{2}$ Institute of Ocean Energy, Saga University, 1, Honjo-machi, Saga-shi, Saga 840-8502, Japan
}

Correspondence should be addressed to Manabu Takao, takao@matsue-ct.jp

Received 2 December 2011; Revised 4 April 2012; Accepted 11 April 2012

Academic Editor: Moon Chan Kim

Copyright (C) 2012 M. Takao and T. Setoguchi. This is an open access article distributed under the Creative Commons Attribution License, which permits unrestricted use, distribution, and reproduction in any medium, provided the original work is properly cited.

This paper describes the present status of the art on air turbines, which could be used for wave energy conversion. The air turbines included in the paper are as follows: Wells type turbines, impulse turbines, radial turbines, cross-flow turbine, and Savonius turbine. The overall performances of the turbines under irregular wave conditions, which typically occur in the sea, have been compared by numerical simulation and sea trial. As a result, under irregular wave conditions it is found that the running and starting characteristics of the impulse type turbines could be superior to those of the Wells turbine. Moreover, as the current challenge on turbine technology, the authors explain a twin-impulse turbine topology for wave energy conversion.

\section{Introduction}

Several of the wave energy devices being studied under many wave energy programs in the United Kingdom, Japan, Portugal, India, and other countries make use of the principle of an oscillating water column (OWC). Figure 1 shows the principle of OWC-based wave energy conversion and its energy conversion chain. In such wave energy devices, a water column which oscillates due to wave motion is used to drive an oscillating air column which is converted into mechanical energy. The energy conversion from an oscillating air column can be achieved by using a system of nonreturn valves for rectifying the airflow, together with a conventional turbine.

On the other hand, the non-return valves can be eliminated by the use of a self-rectifying air turbine, which inherently provides a unidirectional rotation for an alternating airflow. The Wells turbine (Figure 2) [1-13] is of this type and is one of the simplest and probably the most economical turbines for wave energy conversion. However, according to the previous studies, the Wells turbine has inherent disadvantages: lower efficiency, poorer starting characteristics, and higher noise level in comparison with conventional turbines. Consequently, in order to overcome these weak points, a number of self-rectifying air turbines with different configurations have been proposed and improved over decades [14-24].
This paper describes the present state of the art of air turbines for wave energy conversion. The types of turbine included in the paper are summarized as follows.

Wells type turbines:

Wells turbine with guide vanes; turbine with self-pitch-controlled blades; biplane Wells turbine with guide vanes; contrarotating Wells turbine.

Impulse turbines:

impulse turbine with self-pitch-controlled guide vanes; impulse turbine with active-pitch-controlled guide vanes; impulse turbine with fixed guide vanes; McCormick counterrotating turbine.

Radial turbines: radial turbine with fixed guide vanes; radial turbine with active-pitch-controlled guide vanes.

Cross-flow turbine.

Savonius turbine. 


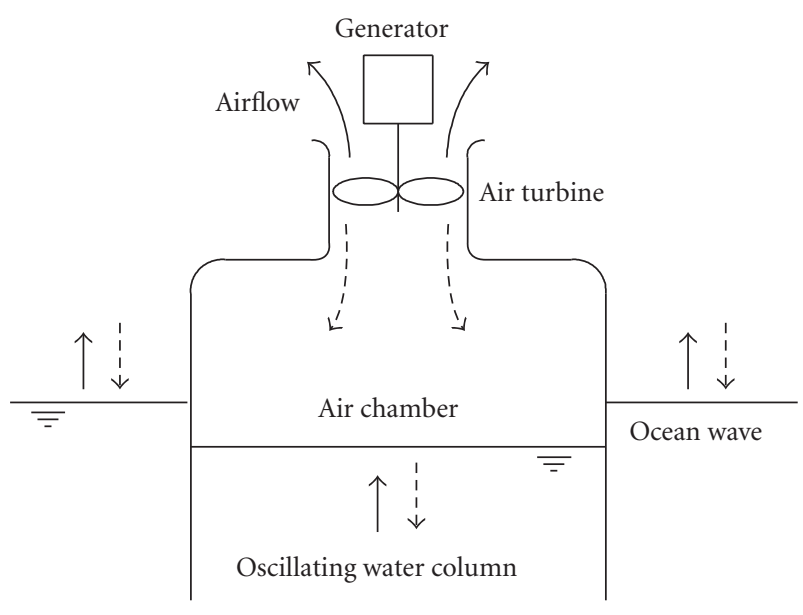

(a) Schematic view

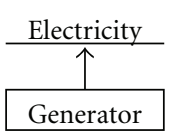

Mechanical energy of rotation

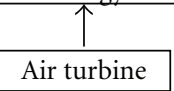

\section{$\uparrow$}

Pressure and kinetic energy of air

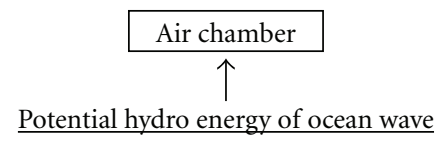

(b) Energy conversion chain

Figure 1: Outline of oscillating water column (OWC) device.

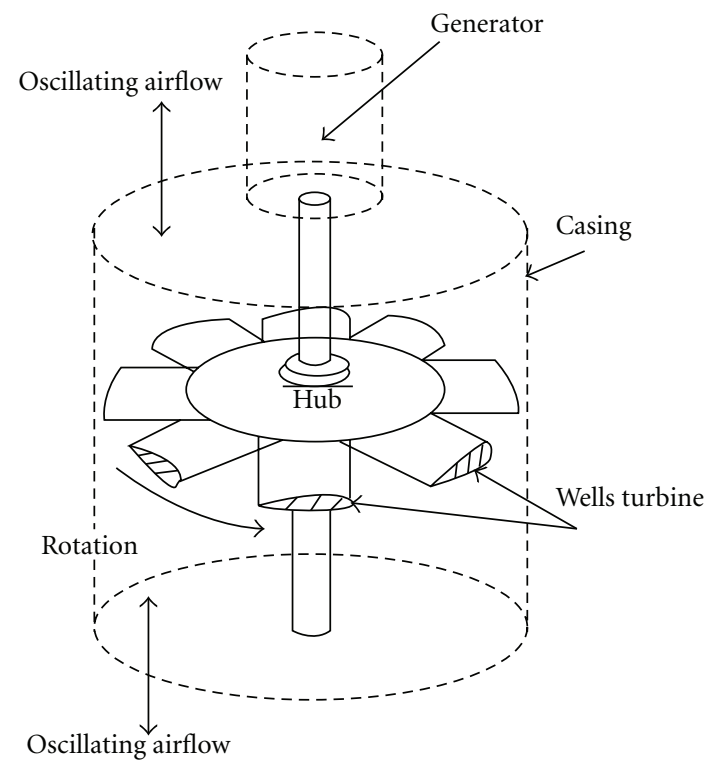

FIgURE 2: Outline of Wells turbine.

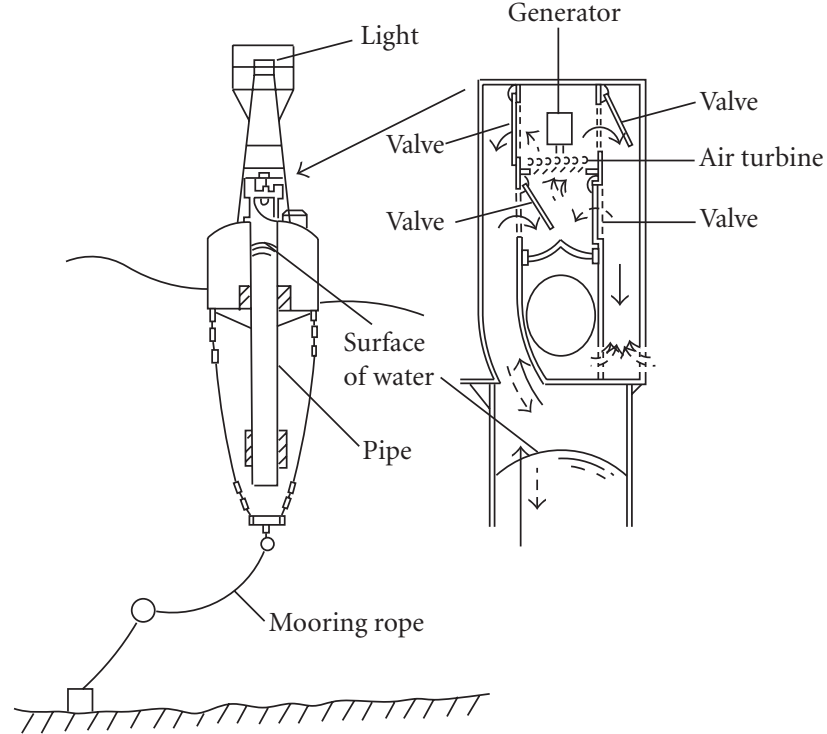

FIgURE 3: Navigation buoy.

Further, the overall performances of the promising turbines under irregular wave conditions, which typically occur in the sea, have been compared by numerical simulation and sea trial.

Finally, as the current challenge on turbine technology, the authors explain a twin-impulse turbine topology for wave energy conversion.

\section{Owc-Based Wave Energy Conversion}

Primary conversion of wave energy is attained by an oscillating system, either a floating body, an oscillating solid member or oscillating water within a structure. Potentially, the most successful device used in the harnessing on wave energy has been the oscillating water column (OWC) wave energy converter. The OWC chamber, either floating or bottom standing, with the immersed end opened to the action of the sea. A reciprocating airflow is created by the action of the free surface of the water within the chamber. The conversion of this airflow into mechanical energy may be achieved by means of a number of devices.

To produce unidirectional flow, a reciprocating airflow may be rectified by a series of nonreturn valves. This unidirectional flow may be used to drive a conventional turbine such as a Francis turbine. An example of practical OWC wave energy converter using the conventional turbine is the navigation buoy, as shown in Figure 3. Based on work by the Japanese wave-energy pioneer Mr. Y. Masuda, more than one thousand wave-powered navigation buoys have been produced since 1965 and marketed worldwide. Some of them have been in operation for more than 30 years. The conventional air turbine is used for the secondary energy conversion in the OWC wave energy converter. However, the airflow rectification system with nonreturn valves is complicated and difficult to maintain. Furthermore, such a system cannot be adopted in a large-scale wave energy device because the valve becomes large. 


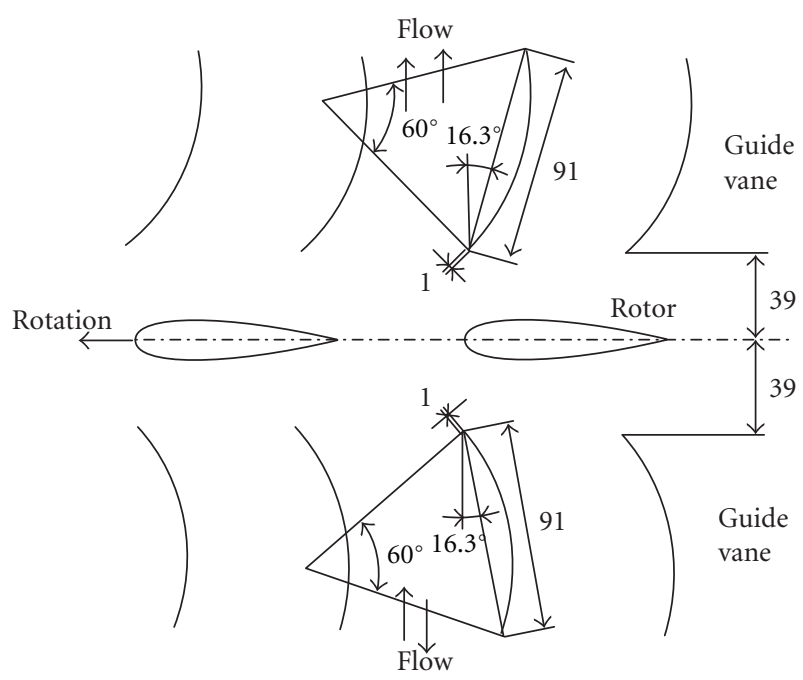

FIgURE 4: Wells turbine with guide vanes (WTGV).

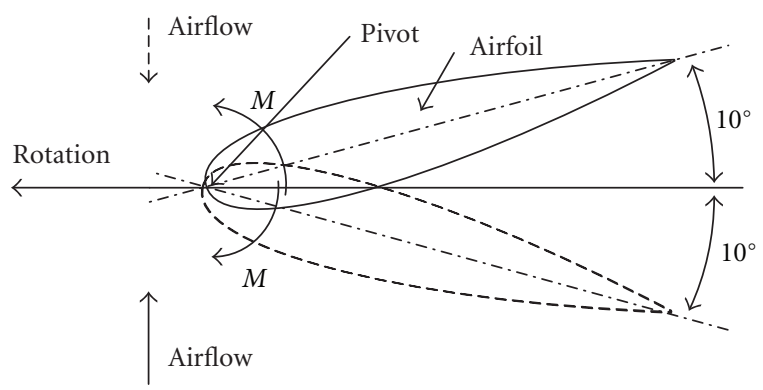

FIgURE 5: Turbine using self-pitch-controlled blades (TSCB).

\section{Self-Rectifying Air Turbines for Wave Energy Conversion}

In OWC-based wave energy conversion, no rectifying valve system is required if the self-rectifying air turbine is used. Many kinds of the self-rectifying air turbines have been proposed and improved so far. The authors describe the present state of self-rectifying air turbines as follows.

3.1. Wells Type Turbine. Figure 4 shows the Wells turbines with guide vanes $[2,3,13]$. The turbine (turbine diameter of $1.7 \mathrm{~m}, 2$ tandem turbines, NACA0021, 8 blades per rotor, rated output of $30 \mathrm{~kW} \times 2$ ) was adopted for the project "Mighty Whale" organized by JMSTEC, Japan [25, 26]. This turbine has been also connected with the Azores Pico Plant supported by EU.

Figure 5 illustrates the turbine with self-pitch-controlled blades $[15,17,24]$. A turbine blade is set on the hub by a pivot located near the leading edge that enables it to oscillate between two prescribed setting angles. As an airfoil set at a certain angle of incidence generates the pitching moment $M$ about a pivot, the turbine blades can oscillate between two setting angles by themselves according to the flow direction, as shown in the figure.

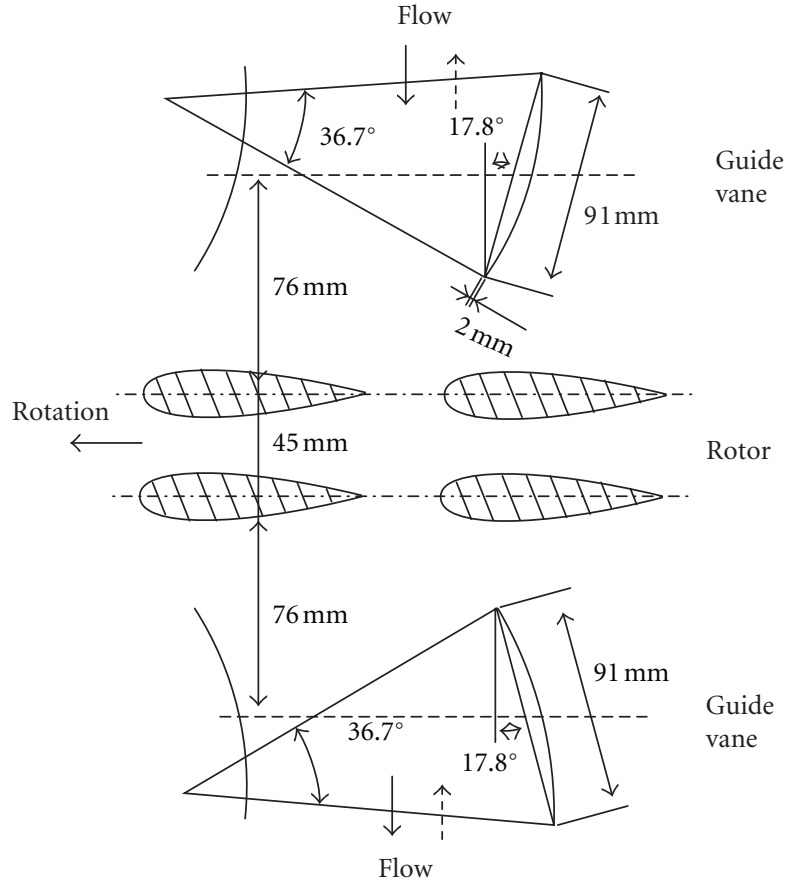

FIGURE 6: Biplane Wells turbine with guide vanes (BWGV).

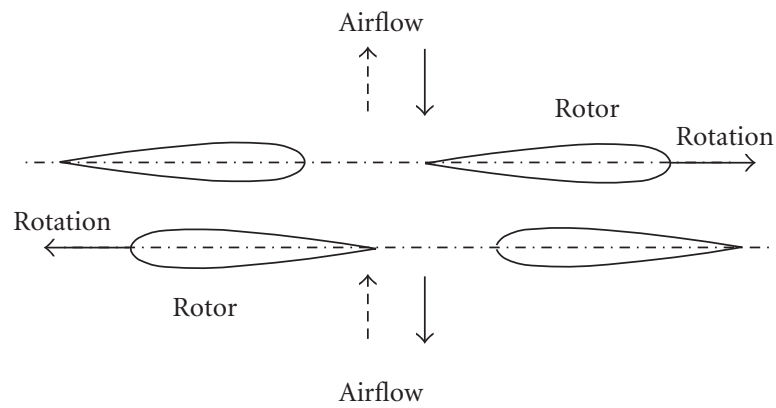

FIGURE 7: Contrarotating Wells turbine.

Figure 6 shows the biplane Wells turbine. This turbine is installed in OWC plant (turbine diameter of $1.2 \mathrm{~m}$, rated output of $75 \mathrm{~kW}$ ), Islay, U.K. [27], where the guide vanes are not used for the turbine.

The contrarotating Wells turbine $[8,28]$ is shown in Figure 7. This was installed in the LIMPET, Islay, U.K. $[29,30]$, which is the world's first commercial wave power station (capacity of $500 \mathrm{~kW}$, turbine diameter of $2.6 \mathrm{~m}, 2$ turbines, NACA0012, 7 blades per rotor). However, detailed information of the turbine characteristics has not been clarified.

3.2. Impulse-Type Turbine. Figure 8 illustrates the impulse turbine with self-pitch-controlled guide vanes. The turbine has guide vanes on both sides of the rotor so as to operate efficiently in an oscillating flow. They are set by pivots on the casing wall. The pivots are located at the end of the guide vane chord close to the rotor so that guide vanes are permitted to move around the pivot by aerodynamic moment 


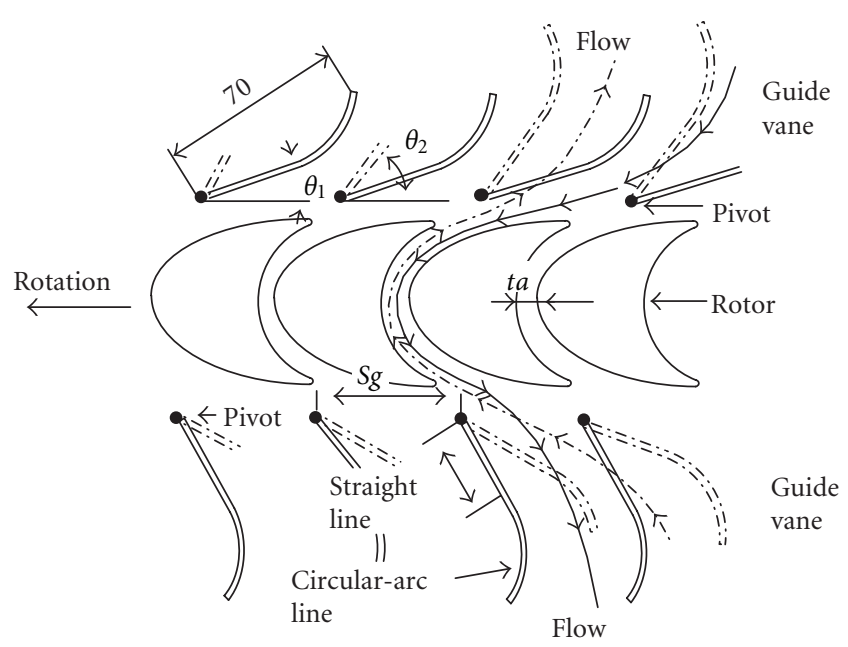

(a) Schematic view

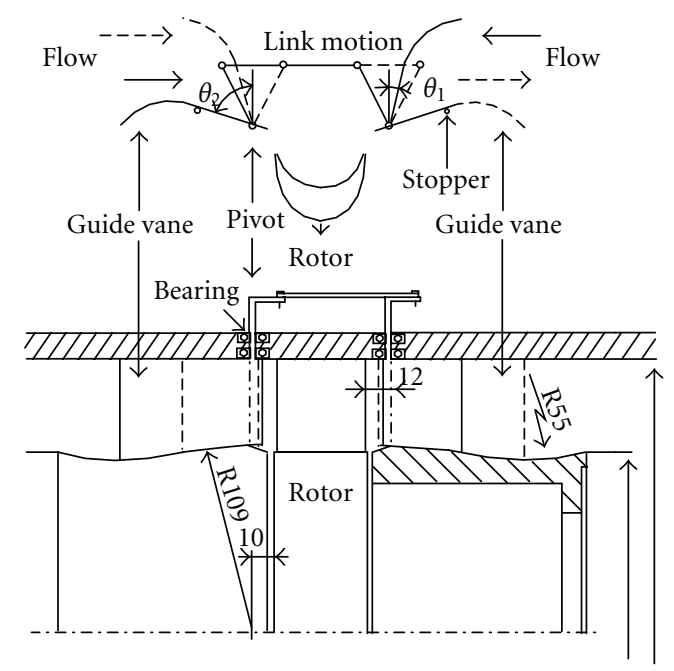

(b) self-pitch-controlled guide vanes connected by links

FIGURE 8: Impulse turbine with self-pitch-controlled guide vanes (ISGV).

induced by a move of oscillating airflow. Every vane on one side of the rotor is connected by a link outside the casing to a vane on the other side of the rotor, as shown in Figure 8(b). This turbine (diameter of $1.0 \mathrm{~m}$ ) has been constructed by NIOT, India $[31,32]$. At NIOT plant, the total efficiency of the plant with this turbine was more than three times of Wells turbine. In recent year, the impulse turbine with active-pitchcontrolled guide vanes by use of hydraulic actuator has been proposed and tested [33].

Figure 9 shows the impulse turbine with fixed guide vanes. The turbine configuration is an impulse type having fixed guide vanes both upstream and downstream, and these geometries are symmetrical with respect to the rotor centerline. This turbine has been installed in floating OWC device "Backward Bent Duct Buoy," as shown in Figure 10 [34].

The outline of the McCormick turbine [35] is sketched in Figure 11. The prototype model of the McCormick turbine

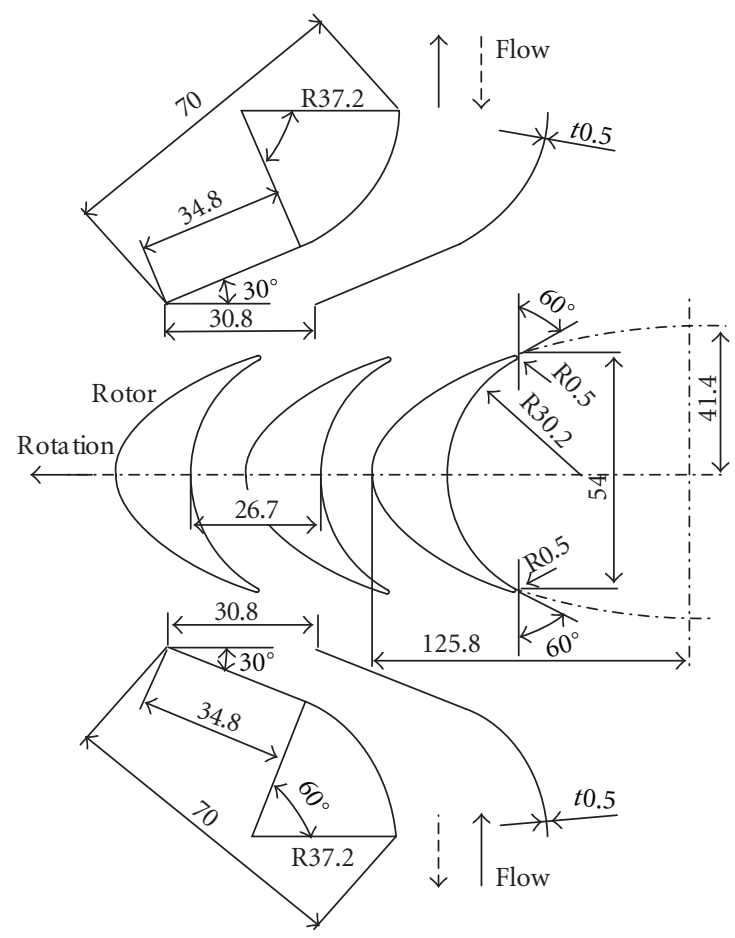

Figure 9: Impulse turbine with fixed guide vanes (IFGV).

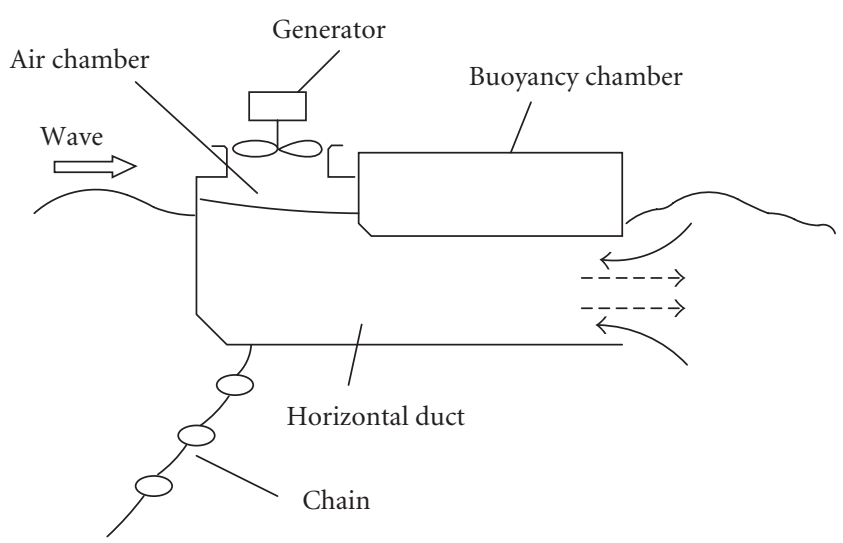

FIGURE 10: Floating-type OWC device "Backward Bent Duct Buoy."

(30 nozzles each turbine, 60 blades per rotor, turbine diameter of $0.99 \mathrm{~m}, 450 \mathrm{rpm}$ nominal design, $1200 \mathrm{rpm}$ with gears) was constructed and tested [18], and average efficiencies near 0.3 appear to have been attained. The disadvantage may be the balance of gearing cost and its noise generation may be a severe problem at specific sites.

3.3. Radial Type Turbine. Figure 12 shows the impulse type radial turbine. The efficiency of the turbine seems to be higher according to the previous studies $[19,20]$, though detailed turbine characteristics are not found in the literature. However, according to a recent research, the efficiency is not so good [36]. In order to overcome this drawback, the radial turbine with active-controlled guide vanes for wave energy conversion has been proposed by the authors [37]. 


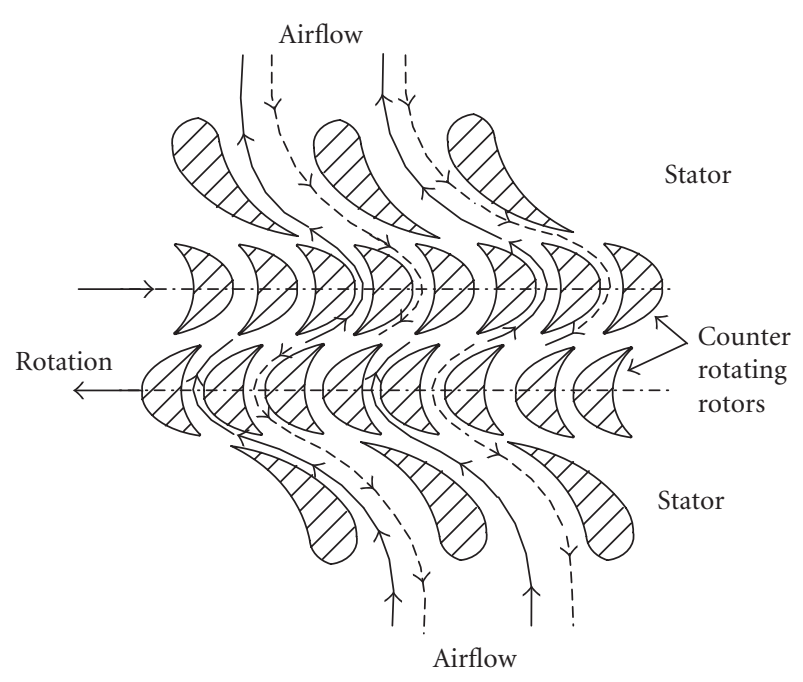

FIGURE 11: McCormick counterrotating turbine.
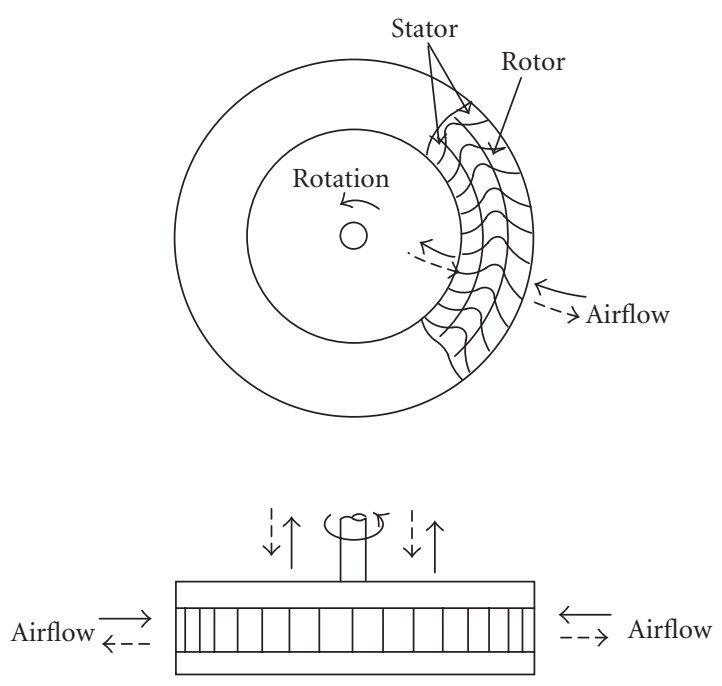

FIgURE 12: Radial turbine with fixed guide vanes.

3.4. Cross Flow Turbine and Savonius Turbine. Many versions of cross flow turbine and Savonius turbine have been proposed so far. In order to obtain some fundamental data for the turbines, the tests were performed under steady flow conditions $[14,16]$. However, in general, they are inferior to Wells type turbines in the starting and running characteristics [38].

\section{Suitable Air Turbine for Wave Energy Conversion}

4.1. Numerical Simulation of Turbine Characteristics. One of the objectives of this chapter is to compare the performances of turbines which could be used for wave power conversion in the near future. Here we should note that the performance of the wave power converter depends on the energy absorption efficiency of OWC, which is closely related to the pressure difference across the turbine, as well as the turbine efficiency.
Therefore, the performances of turbines in connection with OWC under irregular wave conditions are evaluated numerically by using a quasisteady analysis $[4,21]$ and compared from the viewpoints of the starting and running characteristics.

The types of turbine included in this comparative study are as follows. (a) Wells turbine with guide vanes named WTGV in this paper, Figure $4[2,3,13]$. (b) Turbine with selfpitch-controlled blades named TSCBs, Figure $5[15,17,24]$. (c) Biplane Wells turbine with guide vanes named BWGVs, Figure 6 [12]. (d) Impulse turbine with self-pitch-controlled guide vanes named ISGVs, Figure 8 [21, 22]. (e) Impulse turbine with fixed guide vane named IFGV, Figure 9 [23]. In this study the contrarotating Wells turbine was not adopted because the turbine characteristics have not been clarified so far.

The details of turbines adopted in the study are as follows: (a) WTGV (Figure 2); blade profile: NACA0020, tip diameter: $D=298 \mathrm{~mm}$, hub-to-tip ratio: $v=0.7$, aspect ratio: $\mathrm{AR}=0.5$, chord length of rotor: $l_{r}=90 \mathrm{~mm}$, rotor solidity at mean radius $r_{R}: \sigma_{r R}=0.67$, and guide vane solidity at mean radius: $\sigma_{g R}=1.25$. (b) TSCB (Figure 3); NACA0021, $D=298 \mathrm{~mm}, v=0.7, \mathrm{AR}=0.6, l_{r}=75 \mathrm{~mm}, \sigma_{r R}=0.75$, and preset angle of $10^{\circ}$. (c) BWGV (Figure 4); NACA0020, $D=298 \mathrm{~mm}, v=0.7, \mathrm{AR}=0.5, l_{r}=90 \mathrm{~mm}, \sigma_{r R}=0.45$, and $\mathrm{AR}=1.25$. (d) ISGV (Figure 6); $D=298 \mathrm{~mm}, v=0.7$, $t_{a} / S_{r}=0.4\left(t_{a}\right.$ : width of flow path at mean radius, $S_{r}$ : rotor blade space at $r_{R}$ ) (see Figure 6), $l_{r}=54 \mathrm{~mm}$, inlet (or outlet) angle of rotor: $\gamma=60^{\circ}, \sigma_{r R}=2.02, \sigma_{g R}=2.27$, setting angle of upstream guide vane: $\theta_{1}=17^{\circ}$, setting angle of downstream guide vane: $\theta_{2}=72.5^{\circ}$, and sweep angle of rotor: $\lambda=-7.5^{\circ}$. (e) IFGV (Figure 7); $D=298 \mathrm{~mm}, \nu=0.7$, $t_{a} / S_{r}=0.4, l_{r}=54 \mathrm{~mm}, \gamma=60^{\circ}, \sigma_{r R}=2.02, \sigma_{g R}=$ 2.27 , guide vane setting angle of $60^{\circ}$, and $\lambda=-7.5^{\circ}$. Note here that the configurations considered for these turbines are the ones found to be most promising in previous studies $[12,13,17,22,23]$. Furthermore, all of them can start [4] by themselves.

Figure 13 shows the comparison of conversion efficiency of wave energy [39]. For the impulse type turbines, conversion efficiency is quite high at region of large $1 /\left(K \bar{\omega}^{*}\right)\{=$ $V / U_{R}, K$ : nondimensional period, $V$ : reference velocity, and $\bar{\omega}^{*}$ : non-dimensional angular velocity under irregular flow condition $(=\omega \bar{T}, \omega$ : angular velocity of rotor $)\}$ compared with the Wells type turbines. Especially, the value of maximum efficiency for ISGV is about $47 \%$ and over $15 \%$ larger than that of WTGV, which is now mainly used for wave power conversion. Since rotor stall does not occur for the impulse-type turbine, torque can be obtained within a comprehensive region of flow coefficient. Moreover, the difference of the efficiency of the air chamber is considered to be one of the causes that the energy conversion efficiency of wave power conversion using the impulse type turbine is higher than that efficiency using the Wells type turbine. Although ISGV has a disadvantage of maintenance of pivots, even for IFGV, where guide vanes are fixed for simple configuration, the maximum efficiency of IFGV is larger than that of WTGV by about 6\%. On the other hand, the efficiency of TSCB is also considerably higher than that of WTGV. 


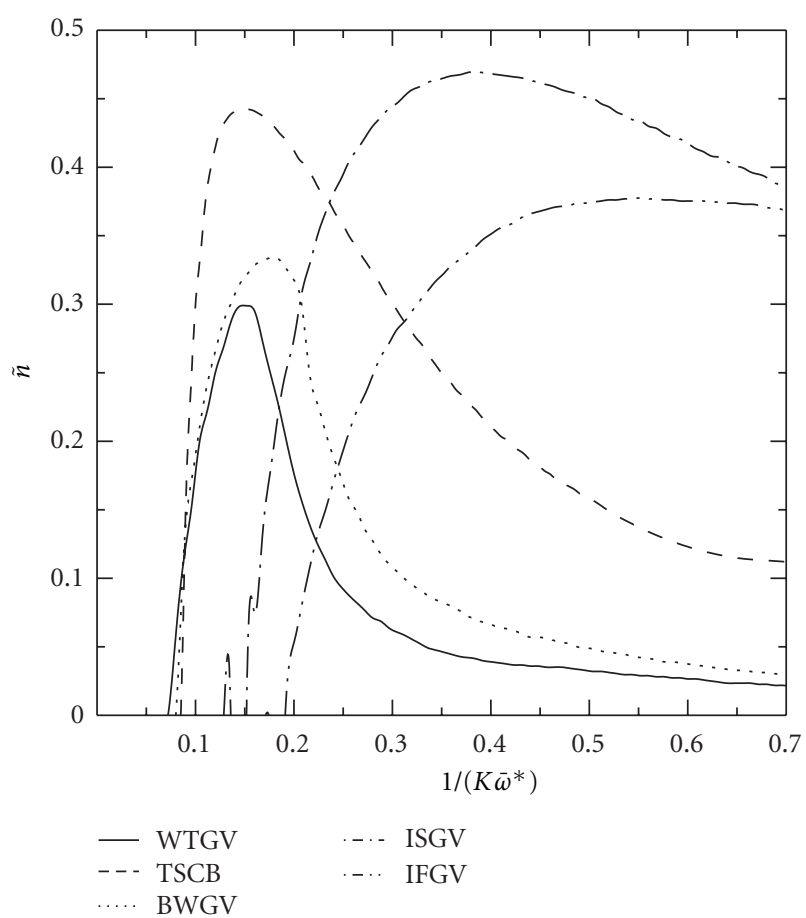

FIGURE 13: Comparison of mean efficiency under irregular wave conditions.

However, it should be noted that maintenance of TSCB is more difficult than that of ISGV because TSCB is using the pitch-controlled rotor blades which is rotating around the shaft at high speed, though ISGV has the pitch-controlled guide vanes.

The starting characteristics for five turbines are shown in Figure 14 [39], where $S$ : nondimensional frequency, $X_{I}$ : nondimensional moment of inertia, $X_{L}$ : nondimensional loading torque, $\bar{t}^{*}$ : dimensionless time under irregular wave condition $\left(\bar{t}^{*}=t / \bar{T}\right), t$ : time, $\bar{T}$ : mean period of wave under irregular wave condition. The impulse type turbine can start in a very short time. This fact means that a generating time of a generator with the impulse turbine is longer than that of the Wells turbine. Furthermore, the rotational speed at operation is much smaller than those of the Wells type turbines. Therefore, when considering the impulse type turbines, it is possible to design an excellent turbine with low operational speed, which is desirable from the viewpoints of noise reduction and mechanical advantage.

4.2. Sea Trial of Air Turbines. A sea trial of wave power plant using an impulse turbine with coreless generator has been carried out at Niigata-Nishi Port, in order to demonstrate usefulness of the turbine for wave energy conversion [40, 41]. As shown in Figure 15, OWC-based wave power plant has been installed at the side of a breakwater and has an air chamber with a sectional area of $4 \mathrm{~m}^{2}(=2 \mathrm{~m} \times 2 \mathrm{~m})$.

The specifications of tested impulse turbine (Figure 16) are as follows. The rotor has a tip diameter of $458 \mathrm{~mm}$, a hubto-tip ratio of 0.7 , a tip clearance of $1 \mathrm{~mm}$, a chord length of $82.8 \mathrm{~mm}$, and a solidity of 2.0. The guide vane with chord

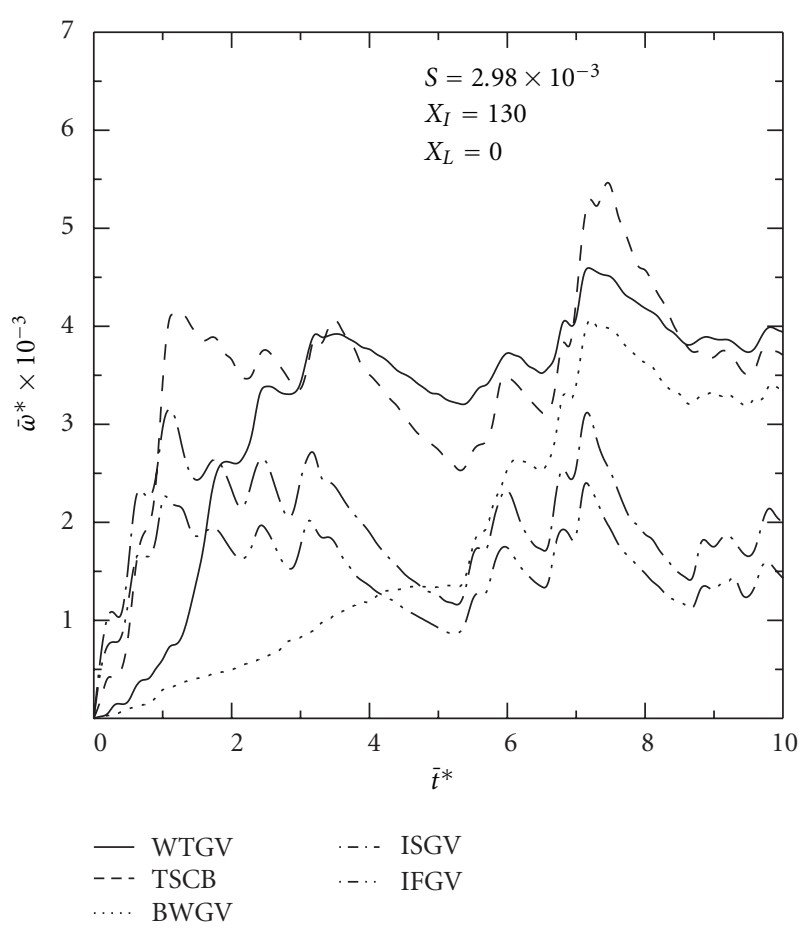

FIGURE 14: Comparison of starting characteristics under irregular wave conditions.

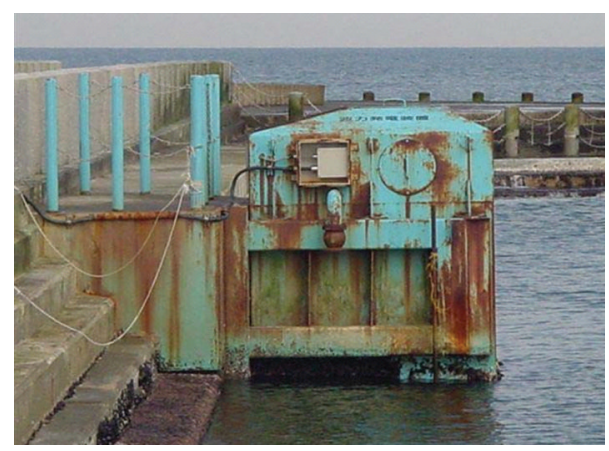

Figure 15: OWC device at Niigata-Nishi Port, Japan.

length of $107.4 \mathrm{~mm}$ is symmetrically installed at the distance of $30.7 \mathrm{~mm}$ downstream and upstream of the rotor. The guide vane has a solidity of 2.27, a thickness ratio of 0.0279 , a guide vane setting angle of $30^{\circ}$ and a camber angle of $60^{\circ}$. The generator is coreless type and can generate electricity at lower rotational speed in comparison with conventional generator. The rated and maximum powers of the generator are $450 \mathrm{~W}$ and $880 \mathrm{~W}$, respectively. The experimental data obtained in the sea trial of wave power plant with the impulse turbine having coreless generator was compared to these of Wells turbine. The specification of Wells turbine (Figure 17) is as follows. The blade profile is NACA0020 with chord length of $131 \mathrm{~mm}$; solidity at mean radius: 0.829 ; aspect ratio: 0.5; tip diameter: $458 \mathrm{~mm}$; tip clearance: $1 \mathrm{~mm}$; hub-to-tip ratio: 0.75 .

In the sea trial, the output and the rotational speed of the generator in the case of a combination of impulse turbine 


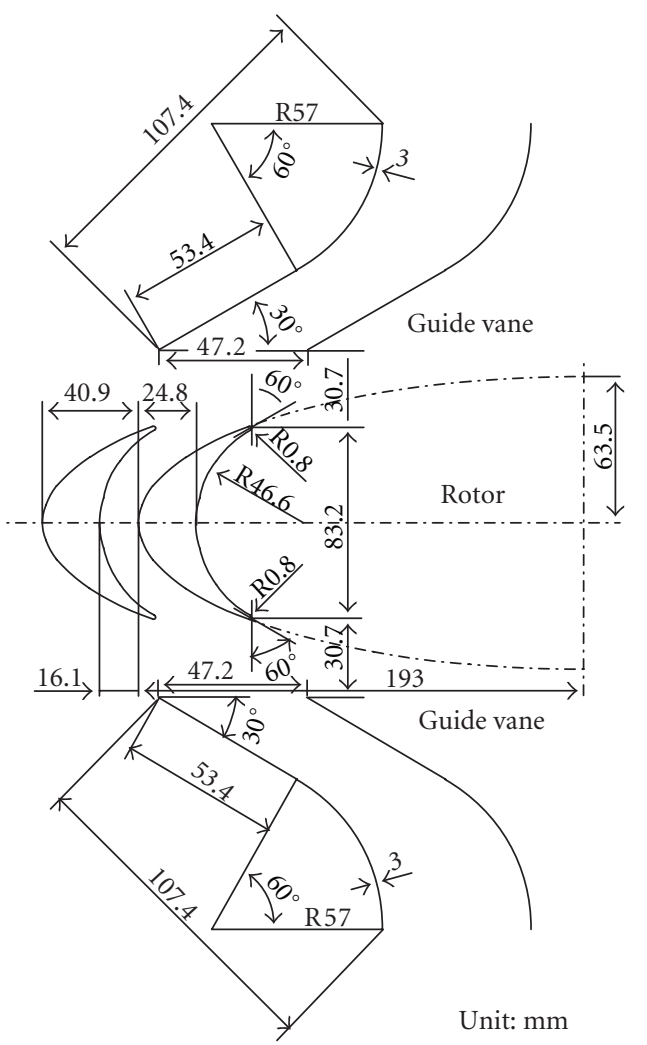

FIgURE 16: Configuration of impulse turbine.

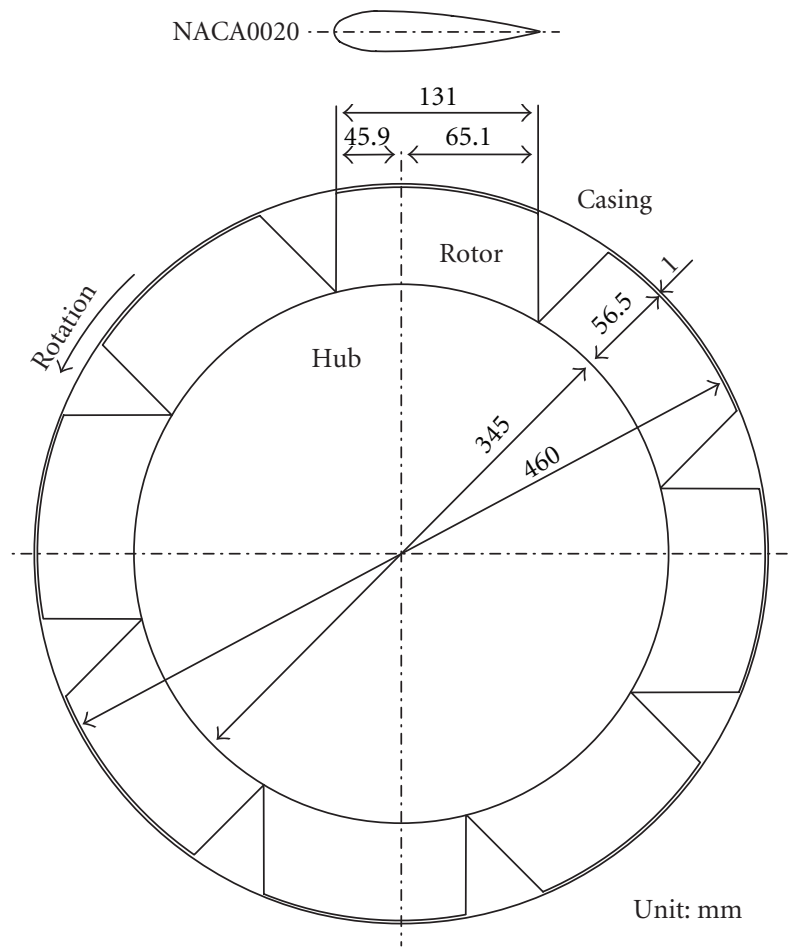

FIgURE 17: Configuration of Wells turbine.

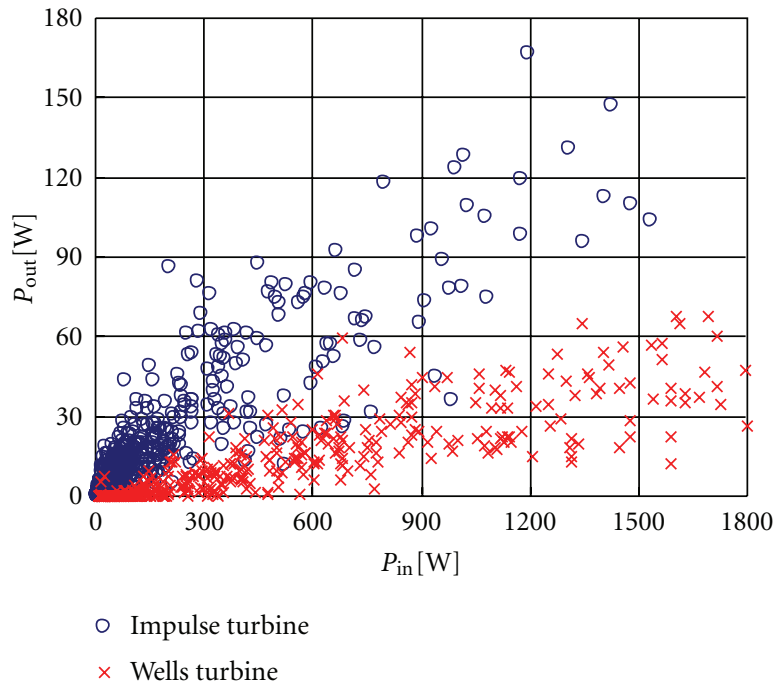

FIGURE 18: Comparison of average output.

and coreless generator were observed for 20 minutes every 2 hours and these were stored in PC. The measurement time in the case of conventional generator is 5 minutes. This measurement is timed to the observation of wave climate by an offshore buoy which is placed at $8 \mathrm{~km}$ away from NiigataNishi Port by Ministry of Land, Infrastructure and Transport. The period of sea trial for the impulse turbine was from June to September in 2007. The period of sea trial for the impulse turbine with conventional was from March to April in 2006. Conversely, the period of sea trial for Wells turbine was from October to November in 2004 and its data was given by Ministry of Land, Infrastructure and Transport.

The performance of the turbine is evaluated by a relationship between the average output of generator $P_{\text {out }}$ and the incident wave power to the plant $P_{\text {in }}$ in the study. The output from the generator is rectified by diode bridge and is used by wire-wound resister with a resistance of $22 \Omega$ in the case of a combination of impulse turbine and coreless generator. On the other hand, a resistance in the case of the conventional generator is controlled. $P_{\text {out }}$ is measured by wattmeter. $P_{w}$ is defined as follows:

$$
P_{\text {in }}=0.5 \times H_{1 / 3}^{2} \times T_{1 / 3} \times W,
$$

where $H_{1 / 3}$ and $T_{1 / 3}$ are the significant wave height and period at the sea trial site, respectively, and $W$ is the width of air chamber.

Figure 18 indicates the results of the sea trials, where the ordinate and the abscissa are the average output $P_{\text {out }}$ and the wave power $P_{\text {in }}$, respectively [40]. It is obviously understood from the figure that $P_{\text {out }}$ in the case of impulse turbine is quite high than that of Wells turbine in whole region of $P_{\text {in }}$. Its value is more than twice the output power of Wells turbine.

Therefore, there is no doubt that the impulse type turbine has better running characteristics than the Wells type turbine. 


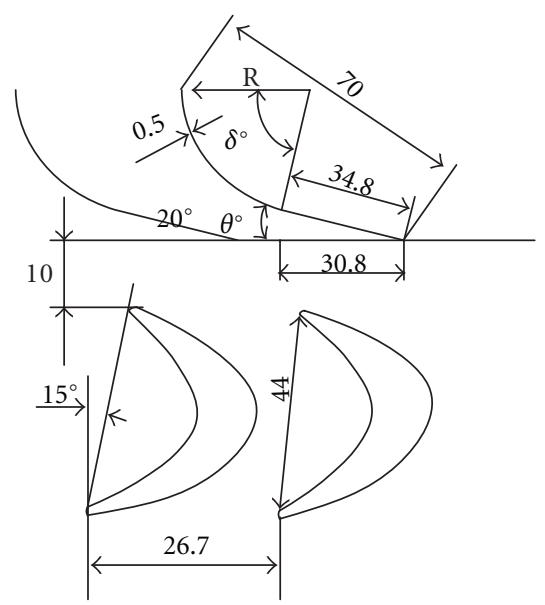

FIgURE 19: Configuration of a unidirectional impulse turbine.

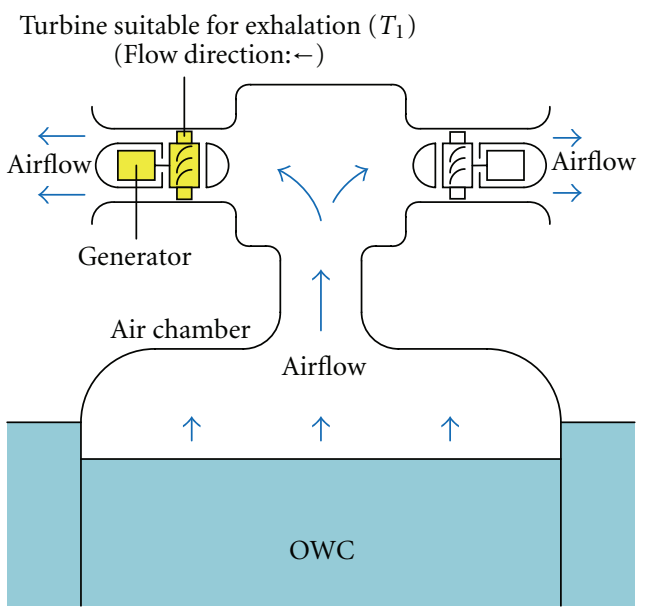

(a) Exhalation

Turbine suitable for exhalation $\left(T_{2}\right)$ (Flow direction: $\leftarrow$ )

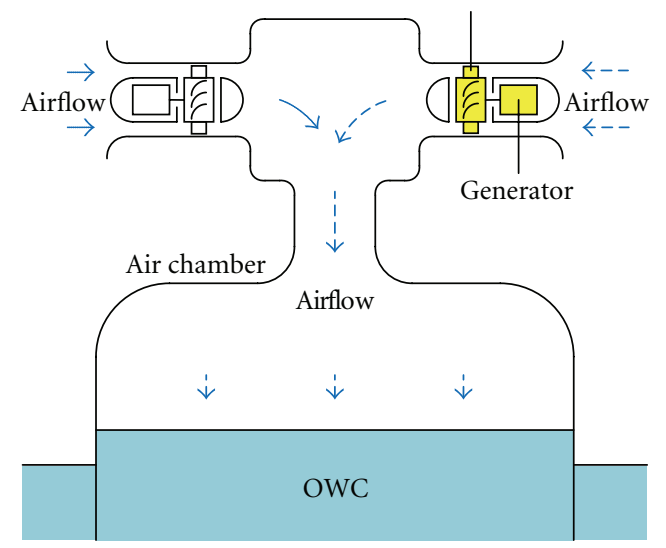

(b) Inhalation

FIgURe 20: Principle of twin impulse turbine.

\section{Development of A Novel Air Turbine for Wave Energy Conversion}

The airflow rectification system with nonreturn valves is complicated and difficult to maintain. Furthermore, such a

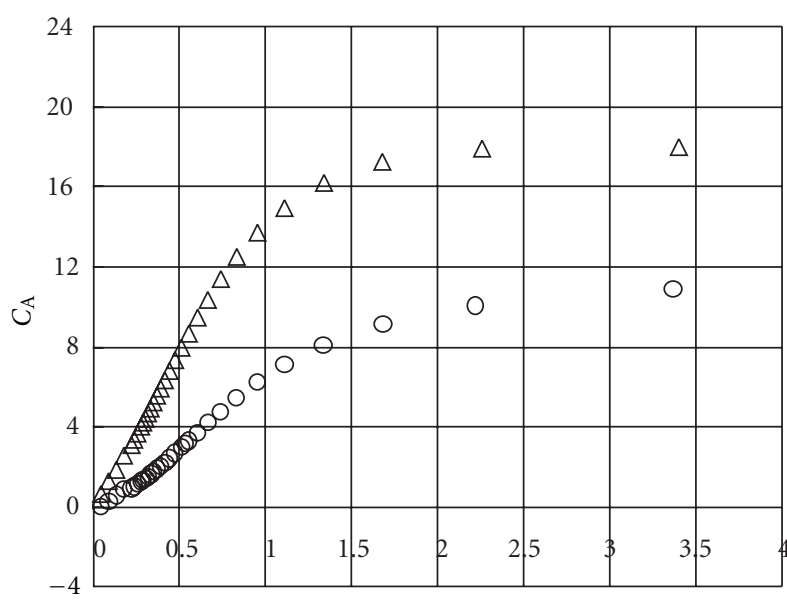

$\phi$

○ Forward

$\Delta$ Reverse

(a) Input coefficient

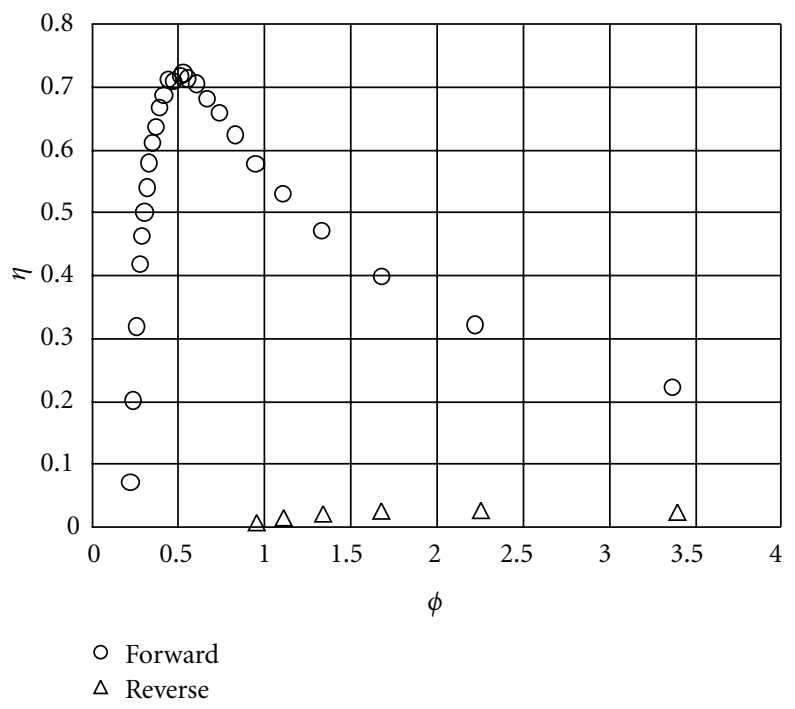

(b) Efficiency

Figure 21: Effects of flow direction on turbine characteristics [45].

system cannot be adopted in a large-scale wave energy device because the valve becomes large. However, a unidirectional turbine (Figure 19) that showed good efficiency over a broad range [42].

A new topology with twin impulse turbine has been proposed, which has a promise of yielding 50\% wave to wire efficiency in an OWC configuration [43-45]. A laboratory model of the concept was built at IIT Madras, India. The basic arrangement of the twin unidirectional topology is shown in Figure 20 [45]. The pressure difference and efficiency of the unidirectional impulse turbine depend on flow direction through the turbine, as shown in Figure 21 [43]. The turbine exploits this phenomenon. The power take-off mechanism utilizes two unidirectional turbines, $T_{1}$ and $T_{2}$ coupled to electrical generators. It was conjectured 
that during intake, the air would flow into the OWC via the turbine $T_{1}$ and during exhaust the air would flow out from the OWC through $T_{2}$. The use of twin unidirectional turbines ensures that, even without the use of valves, each turbine in effect works for half a cycle.

\section{Conclusions}

This paper describes the present status of the art on air turbines for wave energy conversion. The characteristics of air turbines for wave energy conversion proposed so far were investigated by numerical simulation and sea trial under irregular flow conditions. It was found that the impulsetype turbines have the potential to be superior to the Wells type turbines in the overall performances under irregular flow conditions. Furthermore, the authors explained a twinimpulse turbine for wave energy conversion as a novel air turbine for wave energy conversion.

\section{References}

[1] L. M. C. Gato and A. F. O. Falcao, "Aerodynamics of the wells turbine," International Journal of Mechanical Sciences, vol. 30, no. 6, pp. 383-395, 1988.

[2] L. M. C. Gato and A. F. O. Falcao, "Performance of the Wells turbine with a double row of guide vanes," JSME International Journal II, vol. 33, no. 2, pp. 265-271, 1990.

[3] M. Inoue, K. Kaneko, and T. Setoguchi, "Studies on Wells turbine for wave power generator (part 3; effect of guide vanes)," Bulletin of the JSME, vol. 28, no. 243, pp. 1986-1991, 1985.

[4] M. Inoue, K. Kaneko, T. Setoguchi, and S. Raghunathan, "Simulation of starting characteristics of the Wells turbine," in Proceedings of the AIAA/ASME 4th Fluid Mechanics, Plasma Dynamics and Laser Conference, AIAA-86-1122, Atlanta, USA, 1986.

[5] M. Inou, K. Kaneko, T. Setoguchi, and K. Shimamoto, "Studies on Wells turbine for wave power generator (part 4; starting and running characteristics in periodically oscillating flow)," Bulletin of the JSME, vol. 29, no. 250, pp. 1177-1182, 1986.

[6] M. Inoue, K. Kaneko, T. Setoguchi, and T. Saruwatari, "Studies on the Wells turbine for wave power generator (turbine characteristics and design parameter for irregular wave)," JSME International Journal II, vol. 31, no. 4, pp. 676-682, 1988.

[7] K. Kaneko, T. Setoguchi, and M. Inoue, "Performance of Wells turbine in oscillating flow," in Proceedings of the Current Practices and New Technology in Ocean Engineering, vol. 2, pp. 447-452, ASME, New Orleans, La, USA, 1986.

[8] S. Raghunathan, "The wells air turbine for wave energy conversion," Progress in Aerospace Sciences, vol. 31, no. 4, pp. 335386, 1995.

[9] S. Raghunathan and C. P. Tan, "Performance of Wells turbine at starting," Journal of Energy, vol. 6, pp. 430-431, 1982.

[10] S. Raghunathan, T. Setoguchi, and K. Kaneko, "Effect of inlet conditions on the performance of Wells turbine," Journal of Energy Resources Technology, vol. 111, no. 1, pp. 37-42, 1989.

[11] T. Setoguchi, K. Kaneko, and M. Inoue, "Determination of optimum geometry of Wells turbine rotor for wave power generator (part 1)," in Proceedings of the Current Practices and New Technology in Ocean Engineering, vol. 2, pp. 435-440, ASME, New Orleans, La, USA, 1986.

[12] T. Setoguchi, K. Kaneko, E. Matsuki, H. Hamakawa, and M. Inoue, "Some techniques to improve the performance of biplane Wells turbine for wave power generator," in Proceedings of the 1st Pacific/Asia Offshore Mechanics Symposium, vol. 1, pp. 207-212, Seoul, Korea, June 1990.

[13] T. Setoguchi, M. Takao, K. Kaneko, and M. Inoue, "Effect of guide vanes on the performance of a Wells turbine for wave energy conversion," International Journal of Offshore and Polar Engineering, vol. 8, no. 2, pp. 155-160, 1998.

[14] M. Akabane, H. Suzuki, and K. Yamauchi, "On the cross flow turbine for wave power plant," in Proceedings of the 1st Symposium on Wave Energy Utilization in Japan, 1984.

[15] M. Inoue, K. Kaneko, T. Setoguchi, and H. Hamakawa, "Air turbine with self-pitch-controlled blades for wave power generator (estimation of performance by model testing)," JSME International Journal II, vol. 32, no. 1, pp. 19-24, 1989.

[16] M. Katsuhara, F. Kitamura, K. Kajiwara, and Y. Ohta, "Characteristics of air turbines for wave activated generator used as light beacon," in Proceedings of the 2nd Symposium on Wave Energy Utilization in Japan, pp. 83-91, JAMSTEC, 1987.

[17] T. H. Kim, T. Setoguchi, K. Kaneko, and M. Takao, "The optimization of blade pitch settings of an air turbine using selfpitch-controlled blades for wave power conversion," Journal of Solar Energy Engineering, vol. 123, no. 4, pp. 382-386, 2001.

[18] D. Richard and F. B. Weiskopf, "Studies with, and testing of the McCormick pneumatic wave energy turbine with some comments on PWECS systems," in Proceedings of the International Symposium on Utilization of Ocean Waves-Wave to Energy Conversion, pp. 80-102, ASCE, 1986.

[19] M. E. McCormick, J. G. Rehak, and B. D. Williams, "An experimental study of a bidirectional radial turbine for pneumatic energy conversion," in Proceedings of the Mastering the Oceans Through Technology, vol. 2, pp. 866-870, 1992.

[20] M. E. McCormick and B. Cochran, "A performance study of a bi-directional radial turbine," in Proceedings of the European Wave Energy Symposium, pp. 443-448, Edinburgh, UK, 1993.

[21] T. Setoguchi, K. Kaneko, H. Maeda, T. W. Kim, and M. Inoue, "Impulse turbine with self-pitch-controlled guide vanes for wave power conversion: performance of mono-vane type," International Journal of Offshore and Polar Engineering, vol. 3, no. 1, pp. 73-78, 1993.

[22] T. Setoguchi, K. Kaneko, H. Taniyama, H. Maeda, and M. Inoue, "Impulse turbine with self-pitch-controlled guide vanes for wave power conversion: guide vanes connected by links," International Journal of Offshore and Polar Engineering, vol. 6, no. 1, pp. 76-80, 1996.

[23] T. Setoguchi, M. Takao, Y. Kinoue, K. Kaneko, S. Santhakumar, and M. Inoue, "Study on an impulse turbine for wave energy conversion," International Journal of Offshore and Polar Engineering, vol. 10, no. 2, pp. 145-152, 2000.

[24] M. Takao, T. Setoguchi, K. Kaneko, and M. Inoue, "Air turbine with self-pitch controlled blades for wave energy conversion," International Journal of Offshore and Polar Engineering, vol. 7, no. 4, pp. 308-312, 1997.

[25] T. Miyazaki, Y. Washio, and H. Hotta, "Utilization of coastal seas by floating wave energy device "mighty whale"," in Proceedings of the European Wave Energy Symposium, pp. 373-378, Edinburgh, UK, 1993.

[26] Y. Washio, H. Osawa, Y. Nagata, F. Fujii, H. Furuyama, and T. Fujita, "The offshore floating type wave power device "Mighty Whale": Open sea tests," in Proceedings of the 10th International Offshore and Polar Engineering Conference (ISOPE '00), pp. 373-380, Seattle, Wash, USA, June 2000.

[27] A. F. O. Falcao, T. J. T. Whittaker, and A. W. Lewis, "JOULE II preliminary action: European pilot plant study," in Proceedings 
of the European Wave Energy Symposium, pp. 247-257, Edinburgh, UK, 1993.

[28] W. C. Beattie and S. Raghunathan, "A novel contra rotating Wells turbine," in Proceedings of the European Wave Energy Symposium, pp. 191-196, Edinburgh, UK, 1993.

[29] R. G. Alcorn and W. C. Beattie, "Power quality assessment from the LIMPET wave-power station," in Proceedings of the 11th International Offshore and Polar Engineering Conference (ISOPE '01), vol. 1, pp. 575-580, Stavanger, Norway, June 2001.

[30] C. B. Boake, T. J. T. Whittaker, M. Folley, and H. Ellen, "Overview and initial operational experience of the LIMPET wave energy plant," in Proceedings of the 12th International Offshore and Polar Engineering Conference, vol. 1, pp. 586-594, Kitakyushu, Japan, May 2002.

[31] S. Santhakumar, Report of Workshop on Turbine for Ocean Energy Application, Indian Institute of Technology, Madras, India, 1996.

[32] S. Santhakumar, V. Jayashankar, M. A. Atmanand et al., "Performance of an impulse turbine based wave energy plant," in Proceedings of the 8th International Offshore and Polar Engineering Conference (ISOPE '98), pp. 75-80, Montreal, Canada, May 1998.

[33] F. Thiebaut, D. O. Sullivan, P. Kracht et al., "Testing of a floating OWC device with movable guide vane impulse turbine power take-off," in Proceedings of the 9th European Wave and Tidal Energy Conference, CD-ROM, Paper no. 159, Southampton, UK, 2011.

[34] Y. Imai, K. Toyota, S. Nagata, T. Setoguchi, and M. Takao, "An experimental study on generating efficiency of a wave energy converter "Backward Bent Duct Buoy"', in Proceedings of the 9th European Wave and Tidal Energy Conference, CD-ROM, Paper no. 159, Southampton, UK, 2011.

[35] M. E. McCormick, Ocean Wave Energy Conversion, WileyInterscience, New York, NY, USA, 1981.

[36] T. Setoguchi, S. Santhakumar, M. Takao, T. H. Kim, and K. Kaneko, "A performance study of a radial turbine for wave energy conversion," Journal of Power and Energy, vol. 216, no. 1, pp. 15-22, 2002.

[37] M. Takao, Y. Fujioka, and T. Setoguchi, "Effect of pitchcontrolled guide vanes on the performance of a radial turbine for wave energy conversion," Ocean Engineering, vol. 32, no. 17-18, pp. 2079-2087, 2005.

[38] K. Kaneko, T. Setoguchi, and S. Raghunathan, "Self-rectifying turbines for wave energy conversion," in Proceedings of the 1st International Offshore and Polar Engineering Conference (ISOPE '91), pp. 385-392, August 1991.

[39] T. Setoguchi and M. Takao, "Current status of self rectifying air turbines for wave energy conversion," Energy Conversion and Management, vol. 47, no. 15-16, pp. 2382-2396, 2006.

[40] M. Takao, E. Sato, S. Nagata, K. Toyota, and T. Setoguchi, "A sea trial of wave power plant with impulse turbine," in Proceedings of the 27th International Conference on Offshore Mechanics and Arctic Engineering (OMAE '08), Paper no. OMAE200857535, pp. 681-688, Estoril, Portugal, June 2008.

[41] M. Suzuki, M. Takao, E. Sato, S. Nagata, K. Toyota, and T. Setoguchi, "Performance prediction of OWC type small size wave power device with impulse turbine," Journal of Fluid Science and Technology, vol. 3, no. 3, pp. 466-475, 2008.

[42] M. Takao, T. Setoguchi, K. Kaneko, T. H. Kim, H. Maeda, and M. Inoue, "Impulse turbine for wave power conversion with air flow rectification system," International Journal of Offshore and Polar Engineering, vol. 12, no. 2, pp. 142-146, 2002.
[43] V. Jayashankar, S. Anand, T. Geetha et al., "A twin unidirectional impulse turbine topology for OWC based wave energy plants," Renewable Energy, vol. 34, no. 3, pp. 692-698, 2009.

[44] K. Mala, J. Jayaraj, V. Jayashankar et al., "A twin unidirectional impulse turbine topology for OWC based wave energy plants-experimental validation and scaling," Renewable Energy, vol. 36, no. 1, pp. 307-314, 2011.

[45] M. Takao, A. Takami, S. Okuhara, and T. Setoguchi, "A twin unidirectional impulse turbine for wave energy conversion," Journal of Thermal Science, vol. 20, no. 5, pp. 394-397, 2011. 

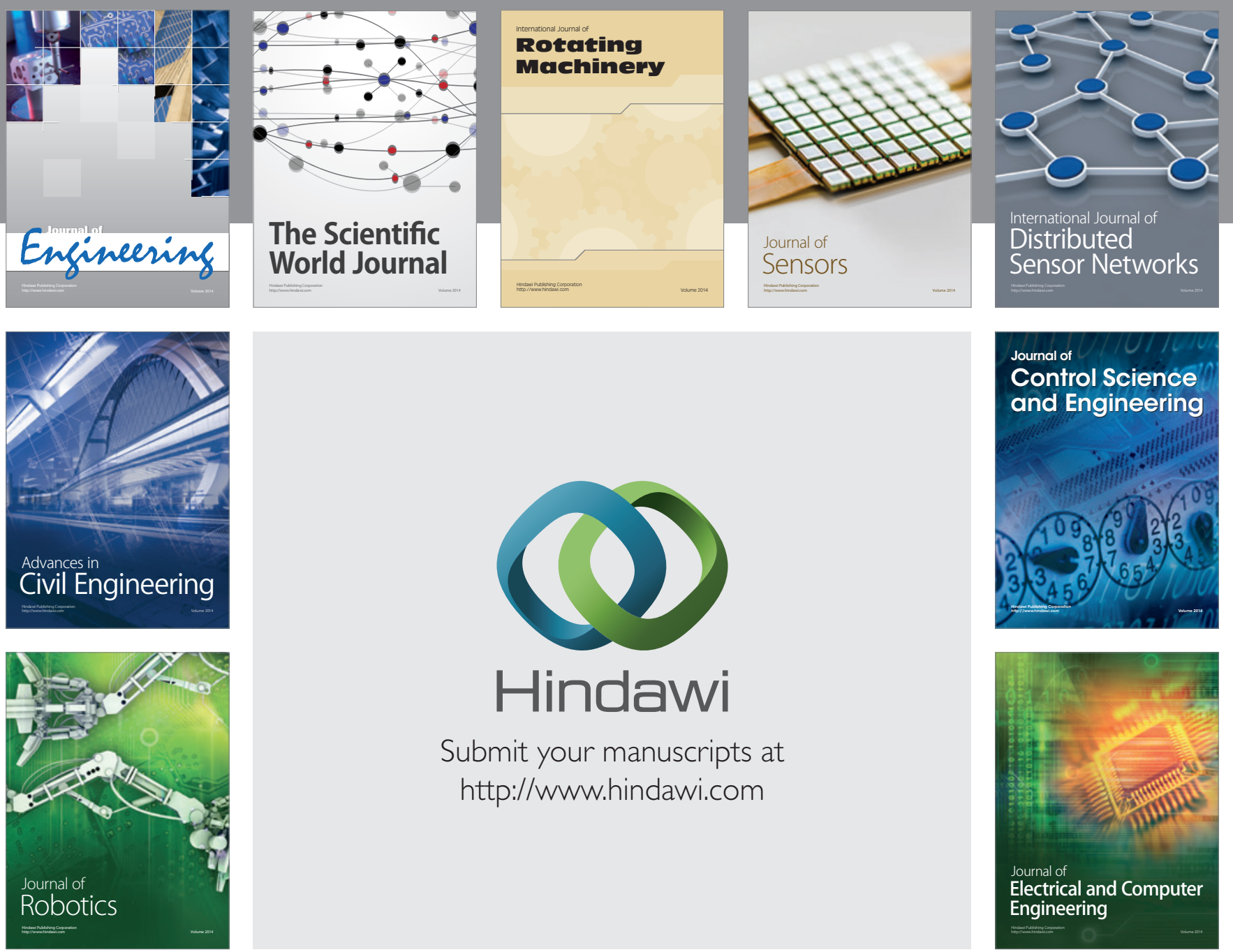

Submit your manuscripts at

http://www.hindawi.com
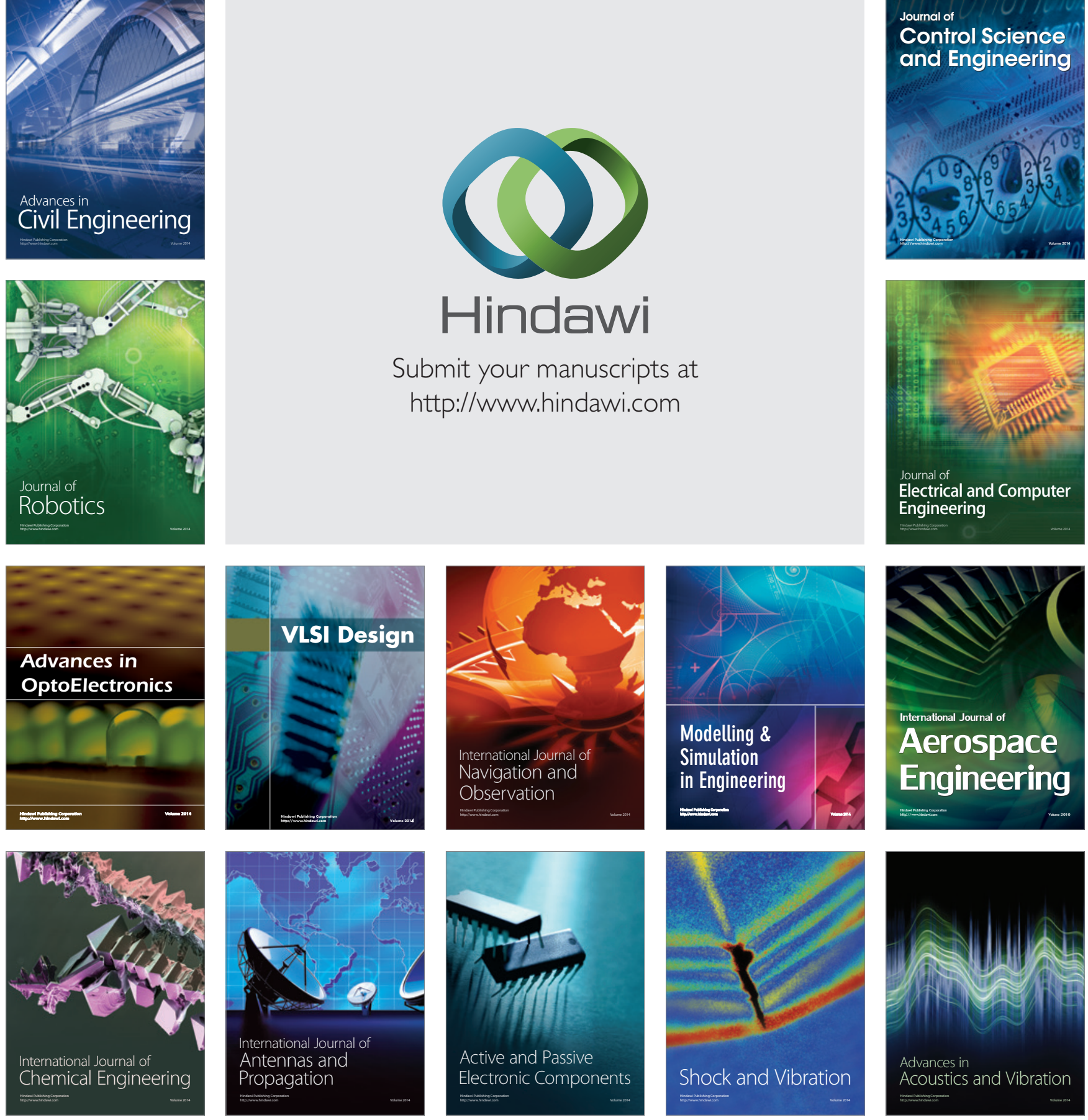